\title{
Genetic Variability, Correlation and Path Analysis in Mungbean [Vigna radiata (L.) Wilczek]
}

\author{
Gaurav Kumar Garg, P.K. Verma and Hari Kesh*
}

Department of Genetics and Plant Breeding, CCS Haryana Agricultural University,

Hisar - 125 004, Haryana, India

*Corresponding author

\section{A B S T R A C T}

\section{Keywords}

Mungbean,

Variability,

Heritability,

Correlation, Genetic

advance.

\section{Article Info}

Accepted:

17 September 2017

Available Online:

10 November 2017
Thirty mungbean genotypes were evaluated for the estimation of genetic variability, heritability, genetic advance, correlation coefficient, and path coefficient analysis for yield and its component traits. A considerable amount of genetic variability was observed among all the genotypes for all the characters under study. GCV \& PCV were highest for seed yield per plant, followed by harvest index, biological yield and number of pods per plant. High genetic advance coupled with high heritability were observed for plant height, number of branches per plant, pod length, seed per pod, 100-seed weight, number of pods per plant, biological yield, seed yield and harvest index. Combined results of correlation coefficient and path analysis revealed that pods per branch, pod length, biological yield and harvest index are major component traits for the improvement of grain yield.

\section{Introduction}

Pulses are the chief source of protein to meet the nutritional requirement of the masses in the world. Pulses have 20 to $25 \%$ protein by weight, which is twice in comparison to wheat and thrice in comparison to rice. Nutrition scientists emphasize the value of pulses as a source of protein and fibre. Biological nitrogen fixation is an important aspect of sustainable and environment friendly agriculture and role of pulses in this context hardly need any emphasis. Legumes, besides helping in maintaining the soil fertility through biological nitrogen fixation, are major source of protein for human consumption and provide high quality crop residue for animal feed. Mungbean which is also known as green gram is one of the important pulse crops in India. It is cheap and rich source of vegetable protein and commonly used as supplement to the normal diet. Mungbean occupies an important position due to its high seed protein content (22-24\%) and it has the ability to restore the soil fertility through symbiotic nitrogen fixation (Malik, 1994). It is rich in essential amino acids specially lysine, which is deficient in most of the cereal grains. Being a short duration crop, it fits well into the intensive rice-wheat cropping system of IndoGangetic plains of India (Brar et al., 2004). It 
can also be grown as intercrop with sugarcane, pigeonpea, poplar and orchards. Thus, there is a great scope of increasing area and production of summer mungbean (Sekhon et al., 2007), however, the productivity of mungbean is still very low. Maximization of yield is major objective in all the crops. Yield is a complex character associated with various contributing characters which are interrelated among themselves. For developing suitable selection strategy the knowledge of genetic variability present in the available germplasm for yield and its associated characters is important. Estimates of genetic parameters provide an indication of the relative importance of the various types of gene effects affecting the total variation of a plant character. Genotypic and phenotypic coefficients of variation and heritability accompanied with genetic advance are very important parameters in improving traits (Denton and Nwangburuka, 2011). Johnson et al., (1955) reported the immense importance of selecting and evaluating varieties for quantitative and yield ability in any breeding programme, before such varieties can be introduced to a given local environment.

\section{Materials and Methods}

The experimental material comprising thirty early maturing genotypes of mungbean were grown during kharif 2014in a randomized block design with three replications at research area of the Department of Dryland Agriculture, Chaudhry Charan Singh Haryana Agricultural University, Hisar (Haryana).The description of genotypes is given in Table 1. Each genotype was sown in two rows of 3 meter length spaced at $45 \mathrm{~cm}$; and $10 \mathrm{~cm}$ between the plants. Hisar is located in global geographical position between $29.09^{\circ} \mathrm{N}$ and $75.43^{\circ} \mathrm{E}$ in western Haryana. All the recommended package of practices was adopted to raise a good crop. Observations for all the traits (except days to $50 \%$ flowering and days to maturity) were recorded by taking five plants per plot. The days to $50 \%$ flowering and days to maturity were computed on plot basis. The data on eleven morphological characters viz. days to maturity, plant height, number of branches per plant, number of pods per plant, number of seeds per pod, pod length were recorded at the time of maturity, whereas observation on days to $50 \%$ flowering was recorded for different genotypes when they attained 50\% flowering stage. The 100-seed weight and seed yield, biological yield and harvest index were recorded after threshing the crop. Analysis of variance for the observations recorded on different characters was carried out as per the standard procedure of Fisher (1930). Genotypic and phenotypic coefficients of variation were estimated according to Burton and Devane (1953). Heritability in broad sense and Genetic advance were worked out as per the procedures of Falconer (1981), Johnson et al., (1955), respectively. Phenotypic and genotypic correlation and path coefficients of variation were computed as per the method given by Dewey and Lu (1959).

\section{Results and Discussion}

The mean sum of squares with respect to various morphological traits has been given in Table 2. The analysis of variance as a measure of variability indicated significant differences amongst the genotypes for all the characters, viz. days to $50 \%$ flowering, days to maturity, plant height $(\mathrm{cm})$, number of branches per plant, number of pods per plant, number of seeds per pod, pod length, 100seed weight $(\mathrm{g})$, seed yield $(\mathrm{g})$, biological yield and harvest index. Rao et al., (2006), Singh et al., (2009), Reddy et al., (2011), Hemavathy et al., (2015) and Dhoot et al., (2017) also reported significant differences for all the characters studied. The presence of sufficient variability indicated that the 
materials of mungbean under study were good enough for further study.

\section{GCV and PCV estimates}

The phenotypic coefficient of variation (PCV) was found higher than that of genotypic coefficient of variation (GCV) for all the traits, suggesting the role of environmental factors on various characters, also suggested by Khajudparn and Tantasawat (2011). The genotypes showed significant differences in respect of all the characters studied (Table 3 ).

High PCV \& GCV estimates were observed for number of pods per plant, biological yield per plant, harvest index and seed yield per plant. Similar finding were also reported by Rao et al., (2006) for pods per plant, seed yield per plant and biological yield per plant, by Pandey et al., (2007) for harvest index and seed yield per plant, by Kumhar and
Chaudhary (2007) for seed yield per plant, and Makeen et al., (2007) and Anand et al., (2016) for number of pods per plant and seed yield. Moderate PCV and GCV were found for plant height, number of branches per plant, pod length, number of seeds per pod and 100 seed weight. Similar results were also observed by Nand and Anuradha (2013) and Pandey et al., (2007) for branches per plant, Rao et al., (2007), Makeen et al., (2007) and Kumhar and Choudhary (2007) for 100 seed weight. Lowest PCV and GCV estimates were obtained for days to $50 \%$ flowering and days to maturity. These results are in conformity with Makeen et al., (2007), Rao et al., (2007), Nan and Anuradha (2013) and Kumhar and Choudhary (2007). The results obtained for PCV and GCV showed that there is considerable possibility of further improvement through intermating followed by appropriate selection for these characters.

Table.1 List of 30 genotypes selected for the study

\begin{tabular}{|l|l|l|l|l|l|}
\hline S. No. & Genotypes & Origin/Source & S. No. & Genotypes & Origin/Source \\
\hline 1. & LGG-460 & ARS, Lamm & 16. & Pusa Ratna & IARI, New Delhi \\
\hline 2. & BDYR-1 & AVRDC, Taiwan & 17. & Pusa-0871 & IARI, New Delhi \\
\hline 3. & BDYR-2 & AVRDC, Taiwan & 18. & Pusa-0672 & IARI, New Delhi \\
\hline 4. & MH-934 & CCS HAU, Hisar & 19. & IPM-02-3 & IIPR, Kanpur \\
\hline 5. & Sattya & CCS HAU, Hisar & 20. & IPM-06-5 & IIPR, Kanpur \\
\hline 6. & Basanti & CCS HAU, Hisar & 21. & KM-2241 & IIPR, Kanpur \\
\hline 7. & MH-421 & CCS HAU, Hisar & 22. & NVL-638 & Nirmal Seeds \\
\hline 8. & GP-69 & CCS HAU, Hisar & 23. & Vamban-2 & NPRC, Vamban \\
\hline 9. & GP-248 & CCS HAU, Hisar & 24. & ML-682 & PAU, Ludhiana \\
\hline 10. & GP-182 & CCS HAU, Hisar & 25. & ML-776 & PAU, Ludhiana \\
\hline 11. & MH-805 & CCS HAU, Hisar & 26. & SML-668 & PAU, Ludhiana \\
\hline 12. & MH-539 & CCS HAU, Hisar & 27. & SML-1018 & PAU, Ludhiana \\
\hline 13. & MH-560 & CCS HAU, Hisar & 28. & AKM-9904 & PRU, Akola \\
\hline 14. & EC-393410 & Exotic collection & 29. & RMG-991 & RAU, Pusa \\
\hline 15. & EC-581523 & Exotic collection & 30. & TBM-11 & TNAU, Coimbatore \\
\hline
\end{tabular}


Table.2 Analysis of variance for various traits in mungbean

\begin{tabular}{|c|c|c|c|c|c|c|c|c|c|c|c|c|}
\hline \multirow{2}{*}{$\begin{array}{l}\text { Source of } \\
\text { Variation }\end{array}$} & \multirow[t]{2}{*}{ Df } & \multicolumn{11}{|c|}{ Mean sum of squares } \\
\hline & & DF & DM & $\mathbf{P H}$ & NB & PPP & PL & SPP & 100SW & SY & BY & HI \\
\hline Replication & 2 & 0.04 & 0.68 & 0.41 & 0.02 & 0.06 & 0.09 & 0.03 & 0.06 & 0.01 & 0.07 & 1.77 \\
\hline Treatment & 29 & $7.29 * *$ & $49.00 * *$ & $58.43 * *$ & $0.57 * *$ & $1.50 * *$ & $1.81 * *$ & $3.11 * *$ & $1.07 * *$ & $1.44 * *$ & $19.18 * *$ & $147.76^{* *}$ \\
\hline Error & 58 & 2.42 & 1.72 & 0.95 & 0.11 & 0.05 & 0.10 & 0.03 & 0.09 & 0.02 & 0.19 & 3.74 \\
\hline C.V.\% & & 4.27 & 2.46 & 3.58 & 11.73 & 9.39 & 5.40 & .96 & 8.46 & 7.59 & 5.46 & 9.40 \\
\hline
\end{tabular}

**Significant at 1\%. DF-Days to flowering (50\%), DM-Days to maturity, PH-Plant height (cm), NB-Number of branches/plant, PPP-Number of pods/plant, PLPod length (cm), SPP-Number of seeds/pod, 100SW-100-seed weight (g), SY-Seed yield/plant (g), BY-Biological yield/plant (g) and HI-Harvest index (\%).

Table.3 Genetic parameters of variation for yield and its component traits in Mungbean

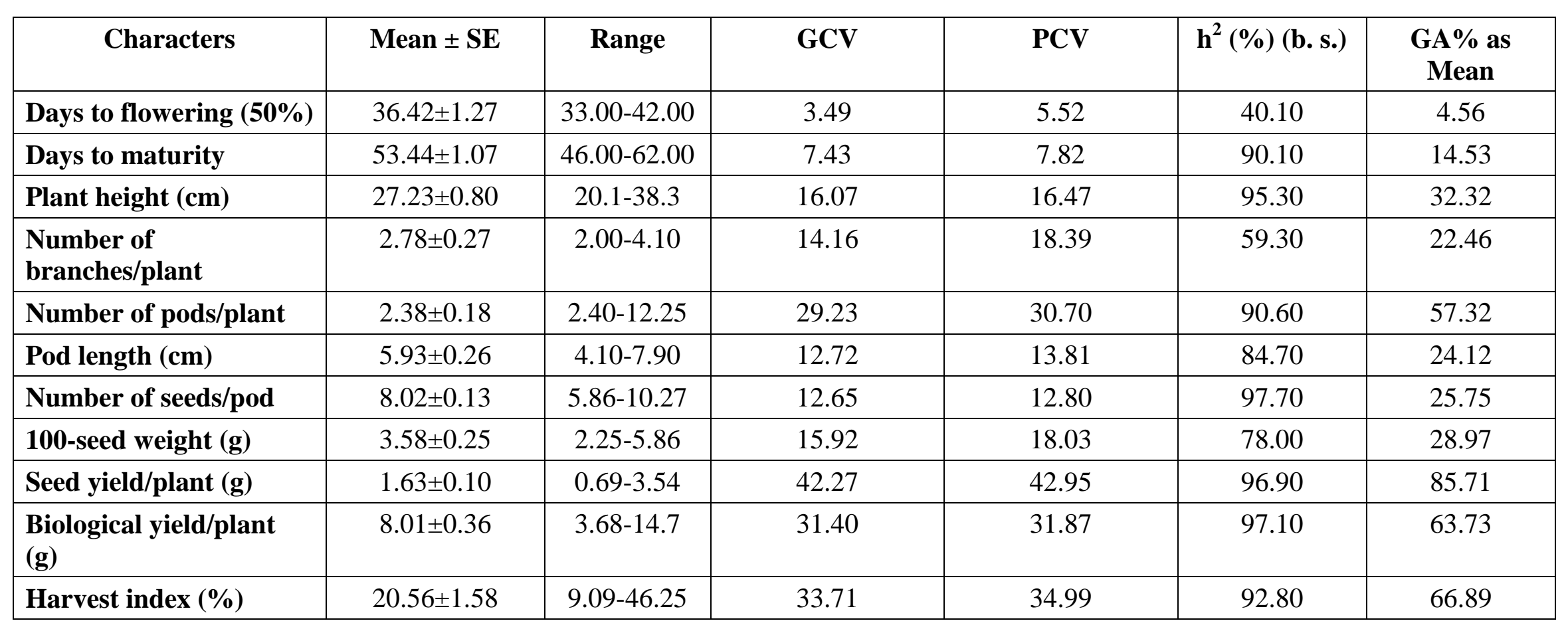


Table.4 Phenotypic (above diagonal) and genotypic (below diagonal) correlation coefficients among various characters in mungbean

\begin{tabular}{|c|c|c|c|c|c|c|c|c|c|c|c|}
\hline Characters & DF & DM & $\mathbf{P H}$ & NB & BY & HI & PPP & $\mathbf{P L}$ & SPP & $100 S W$ & SY \\
\hline DF & 1.000 & 0.182 & -0.154 & 0.043 & -0.176 & -0.165 & $-0.349 * *$ & $-0.261 *$ & $-0.208 *$ & 0.184 & $-0.260 *$ \\
\hline DM & 0.325 & 1.000 & -0.116 & 0.098 & $-0.239 *$ & $-0.359 * *$ & $-0.284 * *$ & $-0.279 * *$ & $-0.239 *$ & $-0.257^{*}$ & $-0.433 * *$ \\
\hline $\mathbf{P H}$ & -0.231 & -0.143 & 1.000 & $0.359 * *$ & $0.396 * *$ & $0.214^{*}$ & 0.098 & $0.374 * *$ & 0.088 & $0.296 * *$ & $0.443 * *$ \\
\hline NB & -0.246 & 0.129 & 0.452 & 1.000 & $0.302 * *$ & 0.189 & -0.010 & 0.088 & 0.104 & 0.105 & $0.346 * *$ \\
\hline BY & -0.287 & -0.257 & 0.407 & 0.383 & 1.000 & -0.090 & $0.308 * *$ & $0.288 * *$ & 0.156 & 0.031 & $0.642 * *$ \\
\hline HI & -0.338 & -0.394 & 0.233 & 0.237 & -0.064 & 1.000 & $0.427 * *$ & 0.173 & $0.274 * *$ & 0.094 & $0.681 * *$ \\
\hline PPP & -0.527 & -0.321 & 0.111 & -0.008 & 0.332 & 0.461 & 1.000 & 0.096 & $0.287 * *$ & $-0.317 * *$ & $0.569 * *$ \\
\hline PL & -0.450 & -0.316 & 0.397 & 0.140 & 0.297 & 0.222 & 0.105 & 1.000 & $0.499 * *$ & $0.267 *$ & $0.386^{* *}$ \\
\hline SPP & -0.328 & -0.267 & 0.083 & 0.131 & 0.159 & 0.290 & 0.307 & 0.524 & 1.000 & -0.020 & $0.349 * *$ \\
\hline 100SW & 0.300 & -0.311 & 0.332 & 0.160 & 0.040 & 0.141 & -0.395 & 0.249 & -0.048 & 1.000 & 0.083 \\
\hline SY & -0.479 & -0.465 & 0.461 & 0.437 & 0.664 & 0.682 & 0.604 & 0.430 & 0.359 & 0.125 & 1.000 \\
\hline
\end{tabular}

* Significant at 5 per cent, ** Significant at 1 per cent

DF-Days to flowering (50\%), DM-Days to maturity, PH-Plant height (cm), NB-Number of branches/plant, PPP-Number of pods/plant, PL-Pod length (cm), SPPNumber of seeds/pod, 100SW-100-seed weight (g), SY-Seed yield/plant (g), BY-Biological yield/plant (g) and HI-Harvest index (\%).

Table.5 Direct (diagonal) and indirect path effects of different characters on seed yield per plant in mungbean

\begin{tabular}{|c|c|c|c|c|c|c|c|c|c|c|}
\hline Characters & DF & DM & $\mathbf{P H}$ & NB & BY & HI & PPP & $\mathbf{P L}$ & SPP & 100SW \\
\hline DF & 0.0069 & 0.0022 & -0.0016 & -0.0017 & -0.002 & -0.0023 & -0.0036 & -0.0031 & -0.0023 & 0.0021 \\
\hline DM & 0.0095 & 0.0293 & -0.0042 & 0.0038 & -0.0075 & -0.0116 & -0.0094 & -0.0093 & -0.0078 & -0.0091 \\
\hline $\mathbf{P H}$ & 0.0049 & 0.003 & -0.0213 & -0.0096 & -0.0087 & -0.005 & -0.0024 & -0.0085 & -0.0018 & -0.0071 \\
\hline NB & -0.004 & 0.0021 & 0.0073 & 0.0161 & 0.0062 & 0.0038 & -0.0001 & 0.0023 & 0.0021 & 0.0026 \\
\hline BY & -0.19 & -0.1698 & 0.269 & 0.2532 & 0.6612 & -0.0426 & 0.2196 & 0.1962 & 0.1054 & 0.0262 \\
\hline HI & -0.2278 & -0.2656 & 0.1568 & 0.1598 & -0.0434 & 0.6741 & 0.3106 & 0.1494 & 0.1954 & 0.0953 \\
\hline PPP & -0.0495 & -0.0302 & 0.0104 & -0.0008 & 0.0312 & 0.0433 & 0.0939 & 0.0099 & 0.0288 & -0.0371 \\
\hline $\mathbf{P L}$ & -0.0398 & -0.028 & 0.0352 & 0.0124 & 0.0263 & 0.0196 & 0.0093 & 0.0886 & 0.0464 & 0.0221 \\
\hline SPP & 0.0018 & 0.0014 & -0.0005 & -0.0007 & -0.0009 & -0.0016 & -0.0017 & -0.0028 & -0.0054 & 0.0003 \\
\hline 100SW & 0.0089 & -0.0093 & 0.0099 & 0.0048 & 0.0012 & 0.0042 & -0.0118 & 0.0074 & -0.0014 & 0.0298 \\
\hline SY & -0.479 & -0.4647 & 0.4611 & 0.4372 & 0.6636 & 0.6821 & 0.6044 & 0.43 & 0.3594 & 0.125 \\
\hline
\end{tabular}

Residual effect $=0.1568$

DF-Days to flowering (50\%), DM-Days to maturity, PH-Plant height (cm), NB-Number of branches/plant, PPP-Number of pods/plant, PL-Pod length (cm), SPPNumber of seeds/pod, 100SW-100-seed weight (g), SY-Seed yield/plant (g), BY-Biological yield/plant (g) and HI-Harvest index (\%). 


\section{Heritability and genetic advance estimates}

High genetic advance coupled with high heritability were observed for plant height, number of branches per plant, pod length, number of seeds per pod, 100-seed weight, number of pods per plant, biological yield, seed yield and harvest index. This suggested the preponderance of additive gene action with low environmental influence for the determination of these characters and could be effective in phenotypic selection. Similar results were obtained by Hemavathy et al., (2015) for plant height, seed yield per plant and number of pods per plant, Pandey et al., (2007) for plant height, seed yield per plant and harvest index, Degefa et al., (2014) for seed yield per hectare and pods per plant, Rao et al., (2007) for branches per plant, 100 seed weight, harvest index, biological yield per plant and seed yield per plant, Hari Kesh et al., (2017) for number of branches per plant, number of seeds per pod, seed yield per plot and Godakh et al., (2013) for seed yield per plant, 100 seed weight, harvest index, number of branches per plant, and biological yield per plant. The character, days to flowering (50\%) exhibited moderate heritability with low genetic advance may be due to non-additive gene action. High heritability coupled with moderate genetic advance was observed for days to maturity, indicating equal importance of additive and non- additive gene actions. Similar observations were reported in greengram by Singh et al., (2009) for days to $50 \%$ flowering and days to maturity. Contrary to this Rao et al., (2006) and Makeen et al., (2007) reported high heritability and low genetic advance for days to maturity.

\section{Correlation coefficient analysis}

Yield, a complex polygenic trait has a large number of other contributing component traits. Correlation analysis reveals the relationship of dependent variable yield with its independent variables, thus association of various traits would determine their relative significance to improve yield. Seed yield per plant exhibited negative correlation with days to flowering and days to maturity suggesting the importance of short duration genotypes (Table 4). On the other hand seed yield per plant exhibited positive correlation with plant height, number of branches per plant, biological yield per plant, harvest index, number of pods per plant, pod length and number of seeds per pod indicating their importance in increasing yield. Number of pods per plant showed a positive and significant correlation with biological yield, harvest index and seeds per pod, but a negative and significant correlation with days to $50 \%$ flowering and days to maturity. 100seed weight had a positive and significant correlation with plant height and pod length. These results are in conformity with Hemavathy et al., (2015) for number of pods per plant and seeds per pod, Anand et al.,(2016) for number of pods per plant, Baisakh et al., (2016) for plant height, pods per plant, pod length and seed per pod, Makeen et al., (2007) for plant height, number of pods per plant, pod length and number of seeds per pod, Godakh et al., (2013) for harvest index, number of pods per plant, number of primary branches per plant and number of seeds per pod sand Tiwari et al., (2014) for number of pods per plant and harvest index. Singh et al., observed a negative and significant correlation between plant height and 100 seed weight.

\section{Path coefficient analysis}

All the direct effects were less than one which indicates that influences due to multicolinearity were minimal. The critical evaluation of path coefficient for agronomic traits, indicate that harvest index had the highest direct and positive effect on seed yield per plant, followed by biological yield per 
plant, number of pods per plant, pod length, 100-seed weight, days to maturity, number of branches per plant and days to flowering (Table 5).

Similar results were also reported by Rao et $a l$. ., (2006) for harvest index, days to maturity, biological yield per plant, 100 seed weight, pod length, pods per plant, Pandey et al., (2007) for harvest index, biological yield, seed per pod, Hemavathy et al., (2015) for plant height, number of pods per plant and 100 seed weight, Gadhak et al., (2013) for harvest index, biological yield per plant, number of seeds per pod, number of primary branches per plant and Tiwari et al., (2014) for harvest index, pod length, plant height and seeds per pod.

The residual effect (0.157) indicates that the component characters under study were responsible for about $85 \%$ of variability in seed yield per plant. So far from the combined results of correlation coefficient and path analysis, it may be concluded that pods per branch, pod length, biological yield and harvest index are major components of seed yield and should be given top priority while formulating a selection strategy for improvement of yield in green gram.

\section{References}

Anand, G., Anandhi, K. and Paulpandi, V.K. (2016). Genetic variability, correlation and path analysis for yield and yield components in F6 families of Greengram (Vigna radiata (L.) Wilczek) under rainfed condition. Electron. J. Plant Breed., 7:434-437.

Baisakh, B., Swain, S.C., Panigrahi, K.K., Das, T.R. and Mohanty, A. (2016). Estimation of Genetic Variability and Character Association in Micro Mutant Lines of Greengram [Vigna radiata (L.)Wilczek] for Yield Attributes and Cold Tolerance. Legume Genomics Genet., 7:1-9.
Brar, J.S., Bains, T.S., Shanmugasundaram, S. and Singh, S. (2004). Developing short duration mungbean genotypes suitable for rice-wheat cropping system. In, Shanmugasundaram, S. (Eds.), Proc Final Workshop and Planning Meeting, AVRDC-DFID Mungbean Project 20022004, pp. 61-81 Punjab Agricultural University, Ludhiana, Punjab, India.

Burton, G.W. and Dewane, E.H. (1953). Estimating heritability in tall Fasciae (Fescuta arundinacea L.) from replicated clonal material. Agron. J., 45: 478-481

Degefa, I., Petros, Y. and Andargie, M. (2014).Genetic variability, heritability and genetic advance in Mung bean (Vigna radiata L. Wilczek) accessions. Plant Sci. Today, 1(2): 94-98.

Denton, O. A., and Nwangburuka, C. C. (2011).Heritability, genetic advance and character association in six related characters of Solanum anguivi. Asian J. Agric. Sci., 5:201-207.

Dewey, D. R. and Lu, K. H. (1959). A correlation and path coefficient analysis of components of crested wheat grass seed production. Agron. J., 51: 515-518.

Dhoot, R., Modha, K.G., Kumar, D. and Dhoot, M. (2017).Correlations and Path Analysis Studies on Yield and its Components in Mungbean (Vigna radiata (L.) Wilczek). Int.J.Curr.Microbiol.App.Sci., 6(5): 370378.

Falconer, D.S. 1981. Introduction to Quantitative Genetics, 2nd edition. Oliver and Boyd, Edinburg, London, UK, pp. 316.

Fisher, R. (1930). The agreement of field experiment. J. Mini. Agric. Great Britain, 33: 503-513.

Gadakh, S.S., Dethe, A.M. and Kathale, M.N. (2013). Genetic variability, correlations and path analysis studies on yield and its components in Mungbean (Vigna radiata (L.)Wilczek). Bioinfolet, 10(2A): 441447.

Hari Kesh, Yadav, A.S., Sarial, A.K., Khajuria, S. and Jain, B. T. (2017). Genotypic Variability and Character Association 
among Yield and Yield Contributing Traits in Pigeon pea (Cajanus cajan L. Millsp). Res. J.Agric. Sci., 8(1): 194-198.

Hemavathy, A.T., Shunmugavalli, N. and Anand, G. (2015).Genetic variability, correlation and path co-efficient studies on yield and its components in mungbean [Vigna radiata (L.)Wilezek].Legume Res., 38 (4): 442-446.

Johnson, H.W., Robinson, H.F. and Comstock, R.E. 1955. Estimates of genetic and environmental variability in soybean. Agron. J., 47: 314-318.

Khajudparn, P. and Tantasawat, P. (2011).Relationships and variability of agronomic and physiological characters in mungbean. Afr. J. Biotechnol., 10(49): 9992-10000.

Kumhar, S.R. and Chaudhary, B.R. (2007).Genetic diversity and variability in Mungbean [Vigna radiata (L.)Wilczek]. J. Plant Genet. Resour, 20(2): 203-208.

Makeen, K., Abrahim, G., Jan, A. and Singh, A.K. (2007).Genetic variability and correlations studies on yield and its components in mungbean (Vigna radiata (L.)Wilezek). J. Agron, 6(1): 216-218.

Makeen, K., Garard, A. Arif J. and Archana K.S. (2007) Genetic variability and correlation studies on yield and its components in mungbean (Vigna radiata (L). Wilckez). J. Agron., 6: 216-218.

Malik, B. A. (1994). Grain legumes. In: Nazir MS (Ed). Crop Production. (p. 301). National Book.

Nand, M.J. and Anuradha, C. (2013). Genetic variability, correlation and path analysis for yield and yield components in mungbean Vigna radiate L. Wilczec. $J$. Res. ANGRAU 41: 31-39.

Pandey, M.K., Srivastava, N. and Kole, C.R. (2007).Selection strategy for augmentation of seed yield in mungbean (Vigna radiate (L.)Wilczek). Legume Res., 30(4): 243-249.

Rao, C.M., Rao, Y.K. and Reddy, M. (2006).Genetic variability and path analysis in Mungbean. Legume Res., 29(3): 216-218.

Reddy, D. Kodanda R., Venkateswarlu, O., Obaiah, M.C. and Jyothi, S.G.L. (2011).Studies on genetic variability, character association and path co-efficient analysis in green gram. Legume Res., 34 (3): $202-206$.

Sekhon, H.S., Bains, T.S., Kooner, B.S. and Sharma, P. (2007). Grow summer mungbean for improving crop sustainability, farm income and nutrition. ActaHorticulturae, Vol.752, 459-64.

Singh, A., Singh, S.K., Sirohi, A. and Yadav, R. (2009).Genetic variability and correlation studies in green gram (Vigna radiata (L.)Wilczek). Progress. agric., 9(1): 5962.

Tiwari, A., Mishra, A.K. and Nag, S.K. (2014).Correlation and path coefficient analysis for seed yield and its components in Mungbean (Vigna radiata (L.)Wilczek). Trends Biosci, 7(1): 42-45.

\section{How to cite this article:}

Gaurav Kumar Garg, P.K. Verma and Hari Kesh. 2017. Genetic Variability, Correlation and Path Analysis in Mungbean [Vigna radiata (L.) Wilczek]. Int.J.Curr.Microbiol.App.Sci. 6(11): 2166-2173. doi: https://doi.org/10.20546/ijcmas.2017.611.255 